Thabiea : Journal of Natural Science Teaching
Program Studi Tadris Ilmu Pengetahuan Alam
Institut Agama Islam Negeri Kudus
http://journal.stainkudus.ac.id/index.php/Thabiea
p-issn: $2580-8974, e-i s s n: 2655-898 x$

\title{
Peningkatan Prestasi Belajar dan Aktivitas Siswa Melalui Penerapan Pembelajaran Model Discovery Learning (DL) pada Materi Kimia Unsur Kelas XII IPA-6 MAN 2 Kudus
}

\author{
Muhamad Muspahaji \\ Madrasah Aliyah Negeri 2 Kudus, Prambatan Kidul, Kaliwungu, Kudus, 59361 \\ muspachem@gmail.com
}

\begin{tabular}{ll}
\hline KBSTRAK \\
\hline Kata kunci: & Tujuan penelitian tindakan kelas ini adalah untuk mengetahui: pengaruh model \\
discovery learning & Discovery Learning terhadap prestasi belajar siswa pada materi kimia unsur. \\
Kimia unsur & Penelitian ini menggunakan metode eksperimen. Populasi dalam penelitian ini \\
Prestasi belajar & adalah kelas XII IPA 6 Madrasah Aliyah Negeri 2 Kudus. Penelitian dilakukan \\
Aktivitas siswa & dengan dua siklus dan masing-masing siklus terdiri atas empat tahapan, yakni: \\
& perencanaan, pelaksanaan, observasi dan refleksi. Teknik pengumpulan data \\
& menggunakan: dokumentasi, tes, angket, observasi. Hasil penelitian \\
& disimpulkan bahwa: Peningkatan prestasi belajar ditunjukkan dengan: (1) rata- \\
& rata prestasi belajar siswa pada siklus I adalah 6,79 dan pada siklus II adalah \\
& 8,68; (2) ketuntasan belajar siswa pada siklus I sebanyak 14 siswa atau 38,89\% \\
dan yang tidak tuntas sebanyak 22 siswa atau 61,11\%; (3) ketuntasan belajar & klasikal pada siklus I adalah 38,89\% dan pada siklus II mencapai 100,00\%, \\
kinerja (performance) guru juga meningkat. Respon siswa adalah 82,14\% & artinya sangat setuju atau pada katagori tinggi.
\end{tabular}

Key word:

Discovery Learning

Elemental Chemistry

Learning achievement

Student activity

\begin{abstract}
Improving Student Achievement and Student Activity Through The Implementation of Discovery Learning Models in Chemical Element Topic at Class XII IPA-6 MAN 2 kudus. The purpose of this class action research is to find out: the influence of the discovery learning (DL) model on student learning achievement on elemental chemistry; This research is using experimental method. The population in this study was class XII IPA 6 Madrasah Aliyah Negeri 2 Kudus. The study was conducted in two cycles and each cycle consisted of four stages, namely: planning, implementation, observation and reflection. Data collection techniques use documentation, tests, questionnaires, and observations. The results of the study concluded that: Improvement of learning achievement is indicated by: (1) the average student achievement in the first cycle is 6.79 and in the cycle II the cycle is 8.68 ; (2) student completeness in the first cycle students 14 students $38.89 \%$ and those who did not complete 22 students or $61.11 \%$; and (3) classical learning completeness in the first cycle was $38.89 \%$ and in the second cycle reached $100.00 \%$ and the performance of the teacher's performance also increased. Student responses were $82.14 \%$ meaning strongly agreed or in the high category.
\end{abstract}

Copyright @ 2019 Institut Agama Islam Negeri Kudus. All Right Reserved

\section{Pendahuluan}

Indonesia merupakan salah satu negara berkembang di dunia. Saat ini Indonesia sedang memperbaiki kemajuan segala bidang demi mengikuti era globalisasi 4,0. Salah satu bidang yang terus dilakukan perbaikan saat ini adalah bidang pendidikan. Pengembangan sistem

pendidikan dengan cara pengembangan kurikulum. Kurikulum 2013 merupakan kurikulum terbaru yang dikembangkan pemerintah dengan harapan dapat meningkatkan kualitas pendidikan di Indonesia. 
MAN 2 Kudus merupakan madrasah yang menggunakan kurikulum 2013. Pembelajaran yang dilakukan dengan kurikulum 2013 berpusat pada siswa (Student Center Learning). Akan tetapi pada saat kegiatan belajar mengajar pelajaran kimia metode ceramah masih sering digunakan.sehingga pembelajaran masih berpusat pada guru dan siswa cenderung masih pasif di kelas.

Salah satu mata pelajaran yang harus dikuasai oleh siswa MA program Matematika Ilmu Alam (MIPA) adalah Kimia. Hasil belajar mata pelajaran Kimia di MAN 2 Kudus khususnya untuk kelas XII MIPA masih tergolong rendah. Berdasarkan dari analisis angket pembelajaran Kimia di kelas XII IPA 6 banyak siswa menyatakan mereka tidak menyukai pelajaran Kimia. Hal ini disebabkan karena mereka merasa pelajaran kimia merupakan pelajaran yang sulit, banyak rumus yang rumit dan materinya tidak mudah dipahami. Kesulitan yang biasa dialami oleh siswa yaitu dalam mengerjakan soal-soal hitungan dan mengaplikasikan rumus yang tepat untuk soal tersebut.

Mata pelajaran yang kurang dikuasai oleh siswa adalah Kimia pada materi Kimia Unsur. Berdasarkan hasil wawancara dengan guru pengampu mata pelajaran kimia di MAN 2 Kudus, materi Kimia Unsur merupakan materi yang sulit dipahami oleh siswa. Hal ini disebabkan karena materi Kimia Unsur merupakan materi yang membutuhkan pemahaman konsep yang tinggi. Namun pada pembelajaran materi ini, siswa lebih sering menghafalkan konsep dan rumus yang ada, sehingga pemahaman siswa terhadap konsep initerbatas.

Berdasarkan hasil observasi yang dilakukan pada pelajaran Kimia di kelas XII IPA 6 MAN 2 Kudus, dapat diketahui bahwa siswa belum menjadi subyek yang dominan pada proses pembelajaran. Kegiatan siswa di kelas hanya menyimak atau mendengarkan materi yang dijelaskan oleh guru. Komunikasi pada kegiatan belajar mengajar umumnya hanya berlangsung searah yang menyebabkan siswa kurang terlibat dalam proses pembelajaran. Ketika guru meminta pendapat atau mengajukan pertanyaan kepada siswa, hanya sedikit siswa yang antusias dalam merespon. Masih banyak siswa yang cenderung acuh dan tidak memperhatikan bahkan saat siswa yang lain sedang mengemukakan pendapat. Hal ini menunjukkan bahwa minat belajar dari siswa kelas XII IPA 6 masih rendah.

Dari permasalahan yang terjadi pada proses pembelajaran di kelas, diperlukan suatu upaya untuk mengatasi masalah tersebut demi peningkatan kualitas pembelajaran. Oleh karena itu, perlu dilakukannya suatu penelitian tindakan kelas (PTK) dalam rangka memperbaiki mutu praktik pembelajaran di kelas. Penelitian Tindakan Kelas muncul dengan maksud untuk memperbaiki situasi pembelajaran di kelas, yang merupakan inti dari kegiatan pendidikan (Suharjono, 2011)

Salah satu upaya untuk mengatasi permasalahan tersebut adalah dengan penerapan model pembelajaran Discovery Learning. Discovery Learning mengacu pada pembelajaran yang terjadi ketika siswa terlibat dalam pengalaman dan eksperimen, dimana mereka mendapatkan pengetahuan dan konsepnya sendiri (Ahmadi, 2005). Menurut Kosasih (2014) pelajaran yang dapat merangsang timbulnya minat dan perhatian murid harus memberikan kesempatan bagi peran serta guru bahkan rasa keterlibatan bagi siswa. Hamalik (2003) menjelaskan bahwa model pembelajaran Discovery Learning menekankan pentingnya pemahaman suatu konsep melalui keterlibatan siswa secara aktif dalam proses pembelajaran. Model pembelajaran ini menekankan pada pembentukan pengetahuan siswa dari pengalaman selama pembelajaran. Kegiatan pembelajaran dengan cara penemuan ini dapat meningkatkan minat siswa dalam belajar kimia dengan cara yang lebih menyenangkan daripada metode konvensional. Dalam pelajaran sains, kegiatan, yang didasarkan pada penyelidikan menggunakan metode Discovery Learning, dapat digunakan dengan tujuan menarik perhatian siswa dan mengaktifkan mereka untuk lebih berpartisipasi dalam kelas. (Balim, 2006)

Beberapa penelitian menjelaskan bahwa Discovery Learning merupakan model 
pembelajaran yang sesuai untuk meningkatkan minat dan prestasi belajar siswa. Mahmoud (2014) menjelaskan bahwa Discovery Learning membantu memperoleh kegiatan di mana siswa belajar untuk diri mereka sendiri dan menerapkan apa yang mereka ketahui dalam situasi baru, yang akan menyebabkan pencapaian pembelajaran yang efektif. Dengan model pembelajaran ini siswa diharapkan lebih mampu memahami konsep dari materi yang sedang dipelajari sehingga akan berpengaruh pada peningkatan prestasi belajarnya. Penelitian dari Akinbobolaa dan Afolabi (2010) menjelaskan bahwa sumber dari minat siswa dalam ilmu pengetahuan dan teknologi dapat dicapai dengan penerapan Discovery Learning. Dengan demikian diharapkan minat belajar siswa terhadap pelajaran kimia meningkat, sehingga prestasi belajarnya juga dapat meningkat.

Berdasarkan uraian di atas, perlu diadakan Penelitian Tindakan Kelas (Classroom Action Research) untuk meningkatkan Minat dan Prestasi Belajar di MAN 2 Kudus dengan judul, "Peningkatan Prestasi Belajar dan Aktivitas Siswa Melalui Penerapan Pembelajaran Model Discovery Learning (DL) Pada Materi Kimia Unsur Kelas XII IPA-6 MAN 2 Kudus.

\section{Metode Penelitian}

Penelitian ini dilakukan di MAN 2 Kudus. Penelitian ini merupakan Penelitian Tindakan Kelas (PTK) yang dilaksanakan dalam dua siklus, dimana masing-masing siklus terdapat empat tahapan yaitu 1) perencanaan 2) pelaksanaan 3) pengamatan dan 4) refleksi. Subjek penelitian adalah siswaKelas XII IPA 6 Madrasah Aliyah Negeri 2 Kudus Pada Semester Gasal Tahun Pelajaran 2018/2019“.

Sumber data adalah guru dan siswa. Analisis data dalam penelitian ini dilakukan dari awal sampai berakhirnya pengumpulan data. Data yang didapat dari hasil penelitian diolah dan dianalisis secara deskriptif kualitatif. Teknikanalisis kualitatif mengacu pada model analisis Miles dan Huberman dalam Sugiyono (2013) melalui proses reduksi data, penyajian data, penarikan kesimpulan dan verifikasi.
Pada penelitian ini digunakan teknik triangulasi agar didapatkan data yang valid dan menggambar kondisi siswa sesungguhnya. Triangulasi merupakan teknik pemeriksaan keabsahan data yang memanfaatkan sesuatu yang lain di luar data untuk keperluan pengecekan atau sebagai pembanding terhadap data itu. Teknik triangulasi yang digunakan adalah teknik triangulasi metode yang dilakukan dalam mengumpulkan data tetap dari sumber data yang berbeda-beda. Dalam penelitian ini menggunakan metode pengumpulan data melalui observasi, angket, tes danwawancara.

\section{Hasil dan Pembahasan \\ Siklus I}

Pada tahap awal, peneliti dan guru mengkaji silabus yang akan digunakan dalam penelitian. Silabus yang digunakan merupakan silabus Kurikulum 2013 yang disusun oleh Kementerian Pendidikan dan Kebudayaan. Berdasarkan silabus tersebut peneliti menyusun RPP untuk tiga pertemuan pada proses pembelajaran siklus I. Pembelajaran didesain menggunakan model pembelajaran Discovery Learning.

Instrumen yang digunakan sebagai alat evaluasi prestasi belajar adalah soal tes objektif untuk kompetensi pengetahuan, angket penilaian diri untuk kompetensi sikap dan minat, serta lembar observasi untuk kompetensi keterampilan, kompetensi sikap dan minat.

Kegiatan pembelajaran yang telah direncanakan oleh peneliti, kemudian diterapkan di kelas XII MIA 6 MAN 2 Kudus Tahun Pelajaran 2018/2019. Pelaksanaan tindakan siklus I dilakukan selama 4 x 2 JP. Siklus I mulai dilaksanakan tanggal 1 September sampai 30 Nopember 2018. Pembelajaran ini menggunakan model pembelajaran Discovery Learning dengan metode eksperimen dan diskusi.

Pengamatan terhadap siswa dilakukan selama proses pembelajaran berlangsung. Di setiap pertemuan siswa mengidentifikasi kasus yang diberikan oleh guru kemudian merumuskan masalah dari identifikasi tersebut. Kemudian siswa melakukan kegiatan 
eksperimen dan/atau mengkaji literatur untuk mengumpulkan data yang nantinya akan dianalisis selama proses pembelajaran materi kelarutan dan hasil kali kelarutan.

Pada setiap pertemuan dilakukan diskusi kelompok untuk menganalisis data yang telah didapat siswa dari kegiatan eksperimen atau pengkajian literatur. Dari diskusi ini kemudian ditarik kesimpulan dari proses pembelajaran yang telah dilakukan oleh siswa. Hasil penilaian tindakan pada siklus I dapat dilihat pada Tabel 1.

Tabel 1. Hasil Tindakan Siklus I

\begin{tabular}{lll}
$\begin{array}{l}\text { Indikator } \\
\text { Kinerja }\end{array}$ & Ketercapaian $(\%)$ & Ket* \\
\hline Pengetahuan & 67,9 & \\
Klasikal & 38,89 & BT \\
Keterampilan & 100 & T \\
Minat & 61,77 & T \\
\hline
\end{tabular}

*Keterangan: T (Tercapai), BT (Belum Tercapai)

Berdasarkan Tabel 1 dapat diketahui bahwa Indikator yang belum mencapai target adalah kompetensi pengetahuan dan minat. Pada kompetensi pengetahuan ketercapaian sebesar $67,9 \%$. Berdasarkan ketercapaian tiap indikator kompetensi masih ada dua indikator yang belum mencapai target yaitu indikator merumuskan hubungan kimia unsur dan indikator senyawa komplek.

Untuk aspek minat ketercapaiannya sebesar $61,77 \%$. Selama proses pembelajaran siklus I, masih ada beberapa yang kurang antusias selama proses diskusi dan kurang semangat dalam mengerjakan soal yang diberikan oleh guru. Selain itu ada juga beberapa siswa yang hanya diam ketika diskusi walaupun belum mengerti tentang materi yang sedang dipelajari. Untuk hasil penilaian kompetensi sikap dan keterampilan sudah mencapai target yang ditentukan. Ketercapaian kompetensi sikap dan keterampilan masing-masing mencapai $100 \%$. Pada kompetensi sikap tetap dilakukan penilaian pada siklus II karena masih ada satu aspek pada kompetensi sikap yang belum mencapai target yaitu sikap proaktif. Sedangkan untuk kompetensi keterampilan, pada siklus II tidak dilakukan penilaian lagi karena semua aspek keterampilan sudah tercapai.
Berdasarkan hasil yang diperoleh pada siklus I dimana kompetensi pengetahuan dan minat belum mencapai target ketercapaian, maka perlu dilakukan tindakan lebih lanjut dengan melakukan pembelajaran pada siklus II. Pembelajaran pada siklus II ini dilakuakn untuk memperbaiki proses pembelajaran pada siklus I sehingga diharapkan semua indikator kompetensi dapat mencapai targetketuntasan.

\section{SIKLUS II}

Tindakan pada siklus II lebih difokuskan untuk perbaikan terhadap kendalakendala yang ada pada siklus I. Tindakan yang dilakukan adalah pertama, guru lebih banyak berkeliling ke kelompok untuk memastikan semua siswa sudah paham pada materi yang sedang dipelajari. Kedua, guru memberi perhatian yang lebih pada siswa yang mengalami kesulitan dan belum mencapai ketuntasan pada siklus I. Ketiga, siswa lebih banyak diberi kesempatan untuk mengemukakan gagasan dan bertanya mengenai hal yang belum dipahami. Keempat siswa diberi latihan soal yang lebih variatif sehingga dapat mengerjakan soal dengan tingkat kesukaran yang lebih tinggi. Kelima, siswa diberi motivasi untuk dapat berperan aktif dalam pembelajaran sehingga bukan hanya kompetensi pengetahuan saja yang terbangun, tapi kompetensi sikap, keterampilan dan minat belajar siswa juga dapatterbangun.

Instrumen pembelajaran yang digunakan dalam siklus II adalah RPP dan instrumen penilaian meliputi tes objektif, angket dan lembar observasi. Instrumen penilaian yang disusun oleh peneliti pada siklus II hanya soal tes objektif untuk kompetensi pengetahuan saja. Sedangkan angket dan lembar observasi untuk kompetensi sikap dan minat menggunakan instrumen yang sama pada siklus I.

Pelaksanaan tindakan pada siklus II dilakukan dalam 2 x 2 JP dengan alokasi pertemuan pertama untuk proses pembelajaran dan pertemuan kedua untuk evaluasi siklus II. Proses pembelajaran difokuskan padaindicator yang belum mencapai target yaitu indikator merumuskan hubungan kimia unsur dan senyawa komplek. Hasill penilaian tindakan 
selama tindakan siklus II disajikan dalam Tabel 2.

Tabel 2. Hasil Siklus II

\begin{tabular}{lll}
\hline $\begin{array}{l}\text { Indikator } \\
\text { Kinerja }\end{array}$ & Ketercapaian $(\%)$ & Ket* \\
\hline Pengetahuan & 86,8 & $\mathrm{~T}$ \\
Klasikal & 100 & $\mathrm{~T}$ \\
Keterampilan & 100 & $\mathrm{~T}$ \\
Minat & 82,14 & $\mathrm{~T}$ \\
\hline
\end{tabular}

*Keterangan: T(Tercapai), BT (Belum Tercapai)

Secara umum, siswa lebih aktif dalam proses pembelajaran siklus II. Siswa lebih bersemangat dalam mengerjakan soal diskusi dari guru. Semua siswa terlibat aktif dalam diskusi kelompok. Siswa juga mulai berinisiatif untuk membaca buku atau literatur lain untuk menjawab soal diskusi. Selain itu siswa juga lebih responsif dalam Kriteria Sikap menjawab pertanyaan yang diajukan oleh guru. Ketika guru meminta siswa menyampaikan pendapat atau menuliskan jawaban soal ke depan kelas siswa sudah mau melakukannya tanpa harus ditunjuk terlebih dahulu.

\section{Perbandingan Hasil Antar Siklus}

Perbandingan hasil tindakan antar siklus bertujuan untuk mengetahui peningkatan yang terjadi dari siklus I ke siklus II.Berdasarkan hasil penilaian tindakan siklus I dan siklus II diperoleh peningkatan hasil dari semua indikator kinerja yang dinilai.

Tabel 3. Perbandingan Siklus I dan Siklus II

\begin{tabular}{llll}
\hline No & Indikator & Siklus I & Siklus II \\
\hline 1 & Pengatahuan & $67.90 \%$ & $96.67 \%$ \\
2 & Sikap & $59.86 \%$ & $91.11 \%$ \\
3 & Sikap dalam & & \\
& kelompok & $67.89 \%$ & $86.78 \%$ \\
4 & Siswa tuntas & $38.89 \%$ & $100.00 \%$ \\
5 & Siswa tidak tuntas & $61.11 \%$ & $0.00 \%$ \\
6 & Ketuntasan klasikal & $38,89 \%$ & $100.00 \%$ \\
7 & Kinerja Guru & $48.72 \%$ & $97.44 \%$ \\
\hline
\end{tabular}

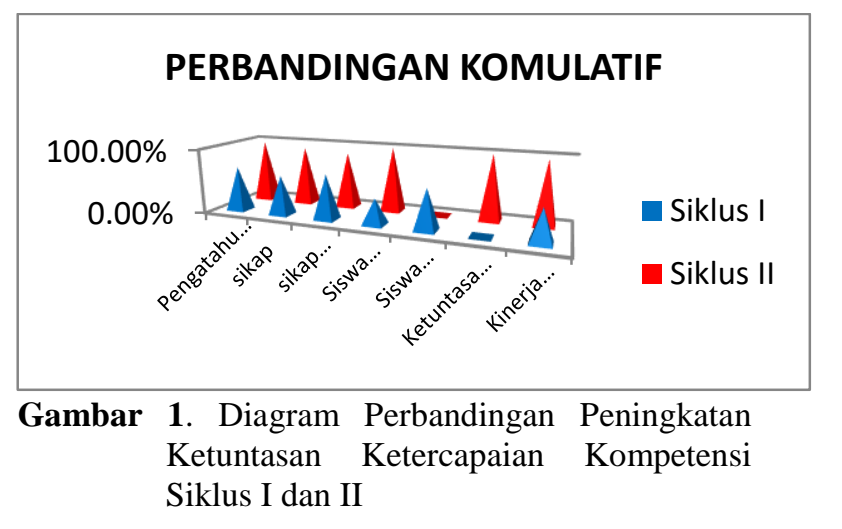

Berdasarkan Gambar di atas, dapat disimpulkan bahwa terdapat peningkatan peresntase siswa yang tuntas dari siklus I ke siklus II. Peningkatan ketuntasan pada kompetensi pengetahuan dari siklus I ke siklus II sebesar $18,9 \%$, bahwa terjadi peningkatan persentase pada kategori siswa sangat baik dari siklus I ke siklus II. Hal ini menunjukkan bahwa pemberian tindakan pada siklus II dapat meningkatkan kompetensi sikap siswa menjadi lebih baik.

Dari Tabel tersebut dapat diketahui bahwa persentase minat belajar siswa dalam kategori sangat baik dan baik mengalami peningkatan dari siklus I ke siklus II. Peningkatan ini sejalan dengan penurunan pada kriteria minat cukup. Hal ini menunjukkan bahwa secara umum minat belajar siswa sudahbaik dan telah mencapai target ketuntasan dilihat dari peningkatan hasil siklus I ke siklus II.

Berdasarkan uraian hasil dan pembahasan, penelitian dengan menggunakan model pembelajaran Discovery Learning dapat dikatakan berhasil dalam meningkatkan minat dan prestasi belajar siswa.Indikator kerja yang meliputi kompetensi pengetahuan, sikap, keterampilan dan minat belajar siswa telah mencapai target.

\section{Kesimpulan}

Berdasarkan hasil penelitian, maka dapat disimpulkan bahwa penerapan model pembelajaran Discovery Learning pada materi kimia unsur terjadi Peningkatan prestasi belajar ditunjukkan dengan rata-rata prestasi belajar siswa pada siklus I adalah 6,79 dan pada siklu siklus II adalah 8,68, ketuntasan belajar siswa pada siklus I siswa 14 siswa atau 38,89\% dan yang tidak tuntas sebanyak 22 siswa atau $61,11 \%$, serta ketuntasan belajar klasikal pada 
siklus I adalah $38,89 \%$ dan pada siklus II mnecapai $100,00 \%$ dan kinerja performance guru juga meningkat. Respon siswa adalah $82,14 \%$ di kelas XII MIPA 6 MAN 2 Kudus tahun pelajaran 2018/2019.

\section{Referensi}

Ahmadi, Abu dan joko Tri Prasetyo. 2005. SBM (Strategi belajar Mengajar). Bandung: Pustaka Setya.

Akinbobola, A. O., \& Afolabi, F. 2010. Constructivist Practices Through Guided Discovery Approach: The Effect on Students' Cognitive Achievement in Nigerian Senior Secondary School Physics. Eurasian journal of physics and chemistry education 2 (1):16-25.

Balım, A., G. 2009 . The Effects of Discovery Learning on Students' Success and Inquiry Learning Skills. Egitim Arastirmalari Eurasian Journal of
Educational Research. vol. 35, 1-20

Hamalik, Oemar. 2003 . Perencanaan Pengajaran. Jakarta: Bumi Aksara

Kosasih. 2014 . Strategi belajar dan pembelajaran, implementasi kurikulum 2013. Bandung: Yarama widya.

Mahmoud, Abdelrahman. 2014. The Effect of Using Discovery Learning Strategy in Teaching Grammatical Rules to first year General Secondary Student on Developing Their Achievement and Metacognitive Skills. International Journal of Innovation and Scientific Research, vol. 5, 146-153

Sugiyono. 2013. Metode Penelitian Kuantitatif, Kualitatif, dan $R \& D$. Bandung: Alfabeta, CV

Suharjono. 2011. Pertanyaan Dan Jawaban Sekitar Penelitian Tindakan Kelas dan Tindakan Sekolah. Malang: Cakrawala Indonesia 